\title{
Analisis Kemampuan Computational Thinking Mahasiswa Dalam Menyelesaikan Masalah Matematika
}

\author{
Yuntawati' ${ }^{1}$, Sanapiah ${ }^{2}$, Lalu Abdul Aziz ${ }^{3}$ \\ ${ }^{1,2}$ Pendidikan Matematika FSTT UNDIKMA \\ ${ }^{3}$ PGSD UNU-NTB \\ Penulis Korespondensi: yuntawati@undikma.ac.id
}

\begin{abstract}
Computational Thinking is a thought process that is needed in formulating a problem and its solution. As a first step to prepare strategies that can be used in improving and developing students 'computational thinking skills, it is necessary to know and first how the students' computational thinking skills. This type of research is descriptive qualitative. The research respondents were 10 students of UNDIKMA mathematics education. Respondent categories are students who have taken Graph courses. The technique of determining respondents is a random sampling method. The research data interview techniques were tests and interviews. The instruments used are two questions to solve math problems. The results shown in solving the first and second questions show that respondents are able to solve problems with the Computational Thinking component. begins with decomposition, abstraction, and algorithms. While the generalization component is not visible in the problem solving process, although there were some respondents who answered incorrectly. This is because the respondents do not understand the questions. Questions are only read once or twice so the information in the questions has not been properly implemented. Even the respondents only saw the simplest paths and ignored the winding paths in solving the second problem.
\end{abstract}

Keywords: Computational Thinking, math problems

\begin{abstract}
Abstrak: Computational Thinking adalah proses berpikir yang diperlukan dalam memformulasikan masalah dan solusinya. Sebagai langkah awal untuk mempersiapkan strategi yang bisa digunakan dalam meningkatkan dan mengembangkan kemampuan Computational Thinking mahasiswa calon guru matematika, maka perlu diketahui dan dianalisis terlebih dahulu bagaimana kemampuan Computational Thinking mahasiswa. Jenis penelitian ini adalah deskriptif kualitatif. Responden penelitian adalah mahasiswa pendidikan matematika UNDIKMA sebanyak 10 mahasiswa. Karakteristik responden adalah mahasiswa yang telah mengambil mata kuliah Grap. Teknik penentuan responden adalah random sampling method. Teknik pengumpulan data penelitian ini adalah tes dan wawancara. Instrumen yang digunakan adalah dua soal pemecahan masalah matematika. Hasil yang ditunjukkan pada penyelesaian soal pertama dan kedua, responden mampu menyelesaikan masalah dengan komponen Computational Thinking. dimulai dengan decomposition, abstraction, dan algorithm. Sedangkan komponen generalization tidak terlihat dalam proses penyelesaian masalah, meskipun ada beberapa responden yang menjawab salah. Hal ini dikarenakan responden kurang memahami soal. Soal hanya dibaca sekali atau dua kali sehingga informasi dalam soal belum benar-benar dipahami. Bahkan responden hanya melihat jalur yang paling sederhana saja dan mengabaikan jalur yang berliku dalam menyelesaikan soal kedua.
\end{abstract}

Kata Kunci: Computational Thinking, masalah matematika.

\section{PENDAHULUAN}

Kemampuan berpikir sistematis, kritis, dan logis adalah kemampuan yang penting dalam pembelajaran di abad ke-21. Masfingatin \& Maharani (2019) mengemukakan bahwa Computational Thinking kemampuan penting yang harus dimiliki siswa pada abad 21, karena dalam prosesnya, pemecahan masalah tidak hanya fokus pada memecahkan masalahnya tapi bagaimana proses pemecahannya. Computational Thinking merupakan keterampilan yang akan memungkinkan siswa berpikir abstrak, 
algoritmik, dan logis, serta siap memecahkan masalah yang kompleks. Computational Thinking adalah proses berpikir yang diperlukan dalam memformulasikan masalah dan solusinya sehingga solusi tersebut dapat menjadi agen pemroses informasi yang efektif dalam menyelesaikan masalah. Adler \& Kim (2017) mengatakan bahwa mengasah Computational Thinking akan bermanfaat dalam dunia pendidikan dan bermanfaat untuk masa depan mereka.

Barr \& Stephenson (2011) membagi komponen Computational Thinking dalam 5 komponen yaitu abstraction, algorithms \& procedures, automation, problem decomposition, parallelization, dan simulation. Selby \& Woollard (2013) mengemukakan 4 komponen Computational Thinking yaitu abstraction, algorithmic thinking, decomposition, evaluation, dan generalization. Sedangkan Angeli et al. (2016) menyajikan 5 komponen Computational Thinking yaitu abstraction, algorithms (including sequencing and flow of control), decomposition, debugging, dan generalization. Pada penelitian ini, komponen-komponen. Computational Thinking mengacu pada komponen-komponen yang dikemukakan Angeli et al. (2016). Debugging biasanya digunakan dalam membuat program, maka proses debugging tidak digunakan dalam penelitian ini.

Komponen-komponen tersebut adalah kunci utama computational Thinking. Abstraction merupakan proses penyaringan detail-detail kecil dari masalah sehingga mudah dipahami dengan mengurangi detail yang tidak perlu (Csizmadia, 2015). Sedangkan algorithm adalah keterampilan untuk merancang serangkaian/tindakan langkah demi langkah tentang bagaimana cara memecahkan masalah (Selby, 2014). Decomposition didefinisikan sebagai keterampilan memecah masalah kompleks kedalam bagian-bagian lebih kecil sehingga lebih mudah dipahami dan diselesaikan (Wing, 2011). Generalization terkait dengan identifikasi pola, persamaan \& hubungan, dan pemanfaatan fitur-fitur (Csizmadia, 2015).

Computational Thinking adalah sebuah pendekatan dalam proses pembelajaran yang digunakan untuk mendukung pemecahan masalah disemua disiplin ilmu, termasuk matematika. Computational Thinking dan matematika memiliki hubungan timbal balik, menggunakan Computational Thinking untuk memperkaya pembelajaran matematika dan sains, dan menerapkan konteks matematika dan sains untuk memperkaya kemampuan Computational Thinking (Maharani, Nusantara, As'ari, \& Qohar, 2019). Kemampuan matematika dianggap sebagai faktor inti yang memprediksi kemampuan siswa untuk belajar. Dalam pembelajaran matematika selalu terkait dengan masalah. Masalah memiliki peran penting dalam matematika. Sebagian besar pembelajaran dihampir semua jenjang pendidikan dirancang sedemikian rupa berdasarkan masalah matematika. Computation Thinking dapat meningkatkan penguasaan materi number sense dan kemampuan aritmatika yang dipengaruhi oleh gaya berpikir, sikap terhadap matematika, dan kebiasaan kognitif (Maharani, Kholid, Pradana, \& Nusantara, 2019).

Berdasarkan uraian di atas, kemampuan Computational Thinking sangat penting dikuasai guru karena guru mempunyai peran penting disetiap aspek keberhasilan akademik siswa. Oleh karena itu perlu mempersiapkan calon-calon guru, dalam hal ini 
khususnya calon guru matematika untuk lebih kompeten dalam meningkatkan dan mengembangkan kemampuan siswa. Meha \& Bullu (2021) menyatakan bahwa mahasiswa harus mempersiapkan diri dengan terus belajar dan berlatih agar keterampilan mengajar sebagai calon guru dapat terbentuk dengan baik.

Beberapa penelitian sebelumnya tentang Computational Thinking, menargetkan siswa SMA dan guru sebagai subyeknya, seperti Nuraisa, dkk. (2019), Kawuri, Budiharti, \& Fauzi (2019) yang meneliti kemampuan Computational Thinking siswa SMA, Angeli, dkk. (2016) meneliti Computational Thinking Curriculum Framework. Sedangkan subyek yang menstransfer ilmu pengetahuan dengan berbagai metodenya adalah guru, dimana guru harus mempunyai dan menguasai berbagai kemampuan termasuk kemampuan Computational Thinking. Oleh karena itu subyek yang dipilih pada penelitian ini adalah calon guru matematika yang membedakan penelitian ini dengan penelitian sebelumnya.

Program Studi (Prodi) Pendidikan Matematika Universitas Pendidikan Mandalika (UNDIKMA) sebagai salah satu prodi yang mencetak calon-calon guru matematika mempunyai tanggung jawab membekali berbagai kemampuan termasuk kemampuan Computational Thinking yang akan menjadi bekal ketika mereka benar-benar menjadi guru sehingga siswa siswinya kelak mempunyai kemampuan Computational Thinking yang bagus. Sebagai langkah awal untuk mempersiapkan suatu strategi yang bisa digunakan dalam meningkatkan dan mengembangkan kemampuan Computational Thinking mahasiswa calon guru matematika, maka perlu diketahui dan dianalisis terlebih dahulu bagaimana kemampuan Computational Thinking mahasiswa.

\section{METODE}

Jenis penelitian ini adalah deskriptif kualitatif. Responden yang terlibat dalam penelitian adalah mahasiswa pendidikan matematika UNDIKMA sebanyak 10 mahasiswa. Karakteristik responden adalah mahasiswa yang telah mengambil mata kuliah Grap. Teknik yang digunakan untuk menentukan responden adalah random sampling method. Teknik pengumpulan data yang digunakan dalam penelitian ini adalah tes dan wawancara. Instrumen yang digunakan adalah dua soal matematika yang merupakan soal pemecahan masalah. Soal tes diadaptasi dari Bebras Indonesia Challenge 2016.

Ada empat tahapan dalam penelitian ini. Pertama, memberikan soal pemecahan masalah ke responden dan meminta mereka menyelesaikan masalah tersebut. Jumlah soal yang diberikan ada 2 soal.

Soal pertama tentang "Upah maksimal". Ana dan Bobi mengisi 6 hari liburnya dengan bekerja pada petani yang sama dan sepakat membagi sama rata upah yang diterima. Ada tiga petani yang masing-masing memberi penawaran yang berbeda. Petani A menawarkan 10 ribu rupiah buat masing-masing (Ana dan Bobi) setiap hari. Petani B hanya akan memberi Bobi 10 ribu rupiah pada hari pertama kemudian setiap berikutnya menaikkan sebesar 10 ribu menjadi 20 ribu, 30 ribu, dan seterusnya, 
sementara ia akan memberi Ana di hari pertama 100 ribu rupiah dan kemudian diturunkan 10 ribu rupiah setiap hari berikutnya menjadi 90 ribu, 80 ribu, dan seterusnya. Petani C tidak tertarik dibantu Bobi, sehingga ia hanya akan memberi seribu rupiah di hari pertama saja dan tidak akan memberi apapun di hari berikutnya. Sementara untuk Ana, ia akan memberikan seribu rupiah pada hari pertama, lalu setiap hari berikutnya dua kali lipat sebelumnya. Jadi Ana akan mendapatkan seribu, 2 ribu, 4 ribu 8 ribu, dan seterusnya.

Masalahnya, kepada petani yang mana mereka (Ana dan Bobi) bekerja sehingga mendapat upah yang paling banyak.

Soal kedua tentang "Jalur jalan Tol". Diberikan peta semua alternatif jalan dari kota Hamper ke kota Mug dimana tujuannya adalah menemukan jalur dengan biaya paling murah dari Hamper ke Mug. Peta jalur jalan Tol ditunjukkan seperti Gambar 1 berikut:

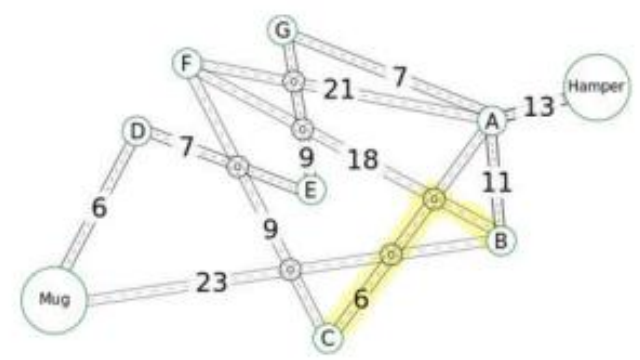

Gambar 1: Deskripsi Soal 2

Tahap kedua, menganalisis komponen-komponen Computational Thinking yang muncul pada hasil penyelesaian masalah responden. Adapun komponen-komponen Computational Thinking dalam penelitian ini dapat dilihat pada tabel 1 berikut:

Tabel 1. Komponen-komponen Computational Thinking

\begin{tabular}{l|l}
\hline \multicolumn{1}{c}{$\begin{array}{c}\text { Komponen } \\
\text { Computational } \\
\text { Thinking }\end{array}$} & \multicolumn{1}{c}{ Aktivitas mahasiswa } \\
\hline Abstraction & $\begin{array}{l}\text { siswa dapat memutuskan suatu objek untuk digunakan atau ditolak, dapat } \\
\text { ditafsirkan untuk memisahkan informasi penting dari informasi yang tidak } \\
\text { digunakan }\end{array}$ \\
\hline Algorithm & $\begin{array}{l}\text { kemampuan merancang langkah demi langkah suatu operasi / tindakan } \\
\text { bagaimana caranya masalah terpecahkan }\end{array}$ \\
\hline Decomposition & $\begin{array}{l}\text { kemampuan untuk memecah masalah yang kompleks menjadi masalah yang } \\
\text { lebih sederhana yang lebih mudah dipahami dan dipecahkan }\end{array}$ \\
\hline Generalization & $\begin{array}{l}\text { kemampuan merumuskan solusi ke dalam bentuk umum sehingga dapat } \\
\text { diterapkan pada masalah yang berbeda, dapat diartikan sebagai penggunaan } \\
\text { variabel dalam menyelesaikan solusi }\end{array}$ \\
\hline
\end{tabular}

Tahap ketiga, melakukan triangulasi data untuk mengkonfirmasi hasil analisis dengan melakukan wawancara mendalam. Pedoman wawancara yang digunakan adalah dengan format terstruktur dan terbuka. 


\section{HASIL DAN PEMBAHASAN}

Hasil yang ditunjukkan pada penyelesaian soal pertama dan kedua, responden mampu menyelesaikan masalah dengan komponen Computational Thinking. meskipun ada beberapa responden yang menjawab salah. Pada soal pertama, responden menyelesaikan masalah secara bertahap dimulai dari kondisi yang diberikan petani A dilanjutkan petani B kemudian petani C. Langkah yang dilakukan responden ini termasuk dalam komponen decomposition, dimana responden memisahkan masalah yang utuh menjadi beberapa bagian. Kemudian menuliskan daftar apa yang diketahui dari masing-masing kondisi secara bertahap sehingga setiap kondisi menjadi daftar sederhana yang lebih mudah untuk dipahami. Langkah ini merupakan proses abstraction. Selanjutnya disusun rancangan langkah penyelesaian dan proses perhitungan untuk mendapatkan solusi masalah. Pada proses ini responden kurang teliti dalam membaca soal sehingga perhitungan yang dilakukan tidak menghasilkan solusi yang benar. Tahap ini bisa dikatakan bahwa responden telah melakukan proses algorithm. Jawaban soal pertama salah satu responden dapat dilihat pada gambar 2 berikut:

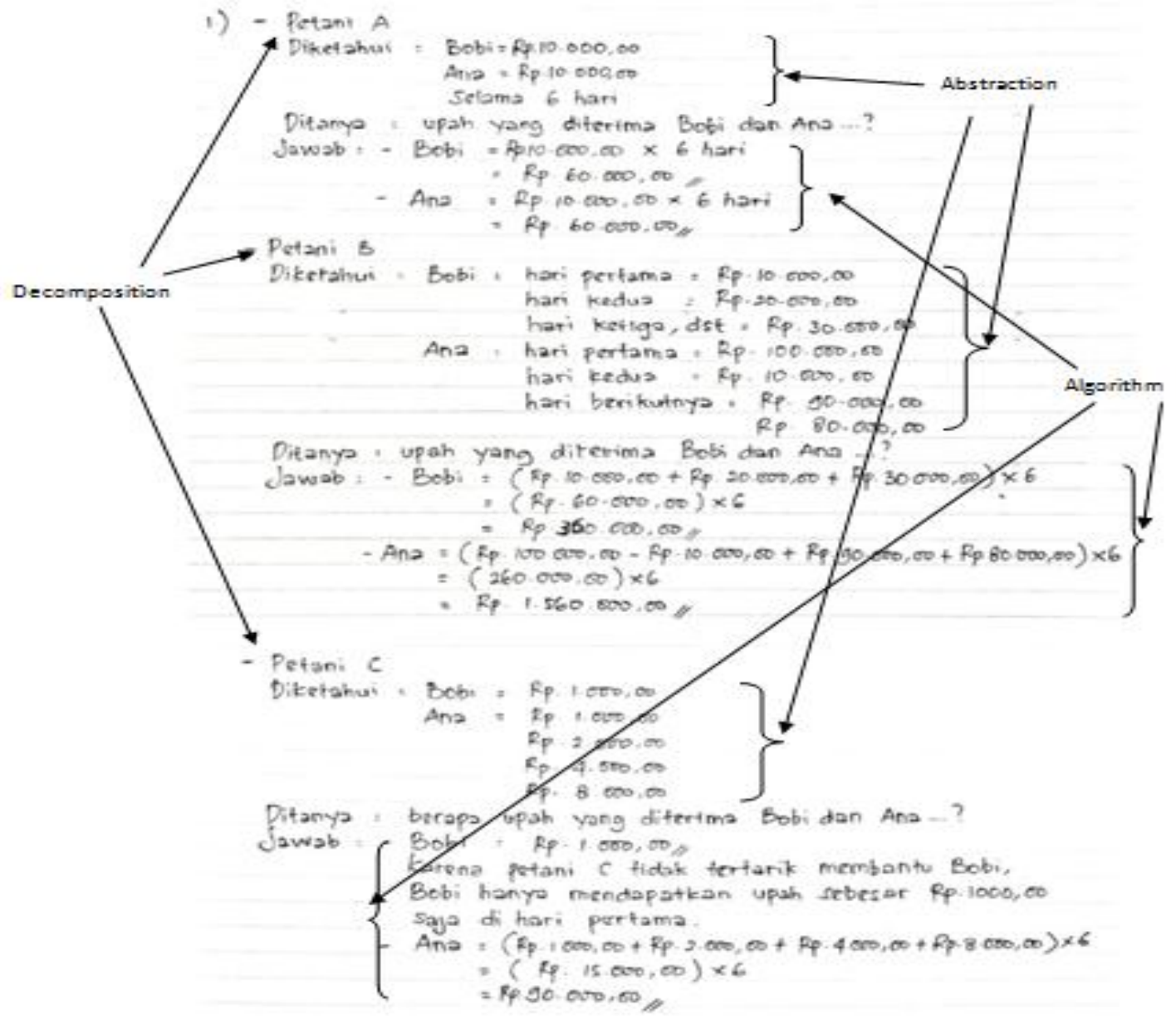

Gambar 2. Jawaban soal 1 salah satu responden

Pada soal kedua, responden memecah jalur jalan tol yang kompleks dengan menggambar salah satu jalur dari kota Hamper ke kota Mug untuk memudahkan 
penyelesaian masalah. Hal ini sejalan dengan Asiyah, dkk (2021) yang menyatakan bahwa rancangan penyajian masalah yang ditampilkan dalam bentuk gambar dan disertai informasi membuat masalah menjadi cukup sederhana untuk dicari pemecahannya. Proses ini memenuhi komponen decomposition yaitu memecah masalah yang kompleks menjadi masalah yang lebih sederhana yang lebih mudah dipahami dan dipecahkan. Akan tetapi, disini responden melakukan kesalahan karena tidak menggambar semua jalur jalan tol yang mungkin dari kota Hamper ke kota Mug sehingga responden tidak bisa membandingkan setiap jalur untuk mendapatkan jalur dengan biaya paling murah. Pada proses ini, responden sekaligus melakukan abstraction dengan menghilangkan jalur-jalur lain yang dianggap tidak digunakan. Komponen algorithm terlihat pada langkah penjumlahan biaya dari kota Hamper ke kota A, kota A ke kota B, dan dari kota B ke kota Mug. Karena responden tidak menggambar setiap jalur jalan tol secara terpisah sehingga jalur yang dipilih bukan merupakan solusi masalah. Ketidaktelitian responden dalam melakukan perhitungan menambah poin kesalahan yang dilakukan responden. Jawaban soal kedua salah satu responden dapat dilihat pada gambar 3 berikut:

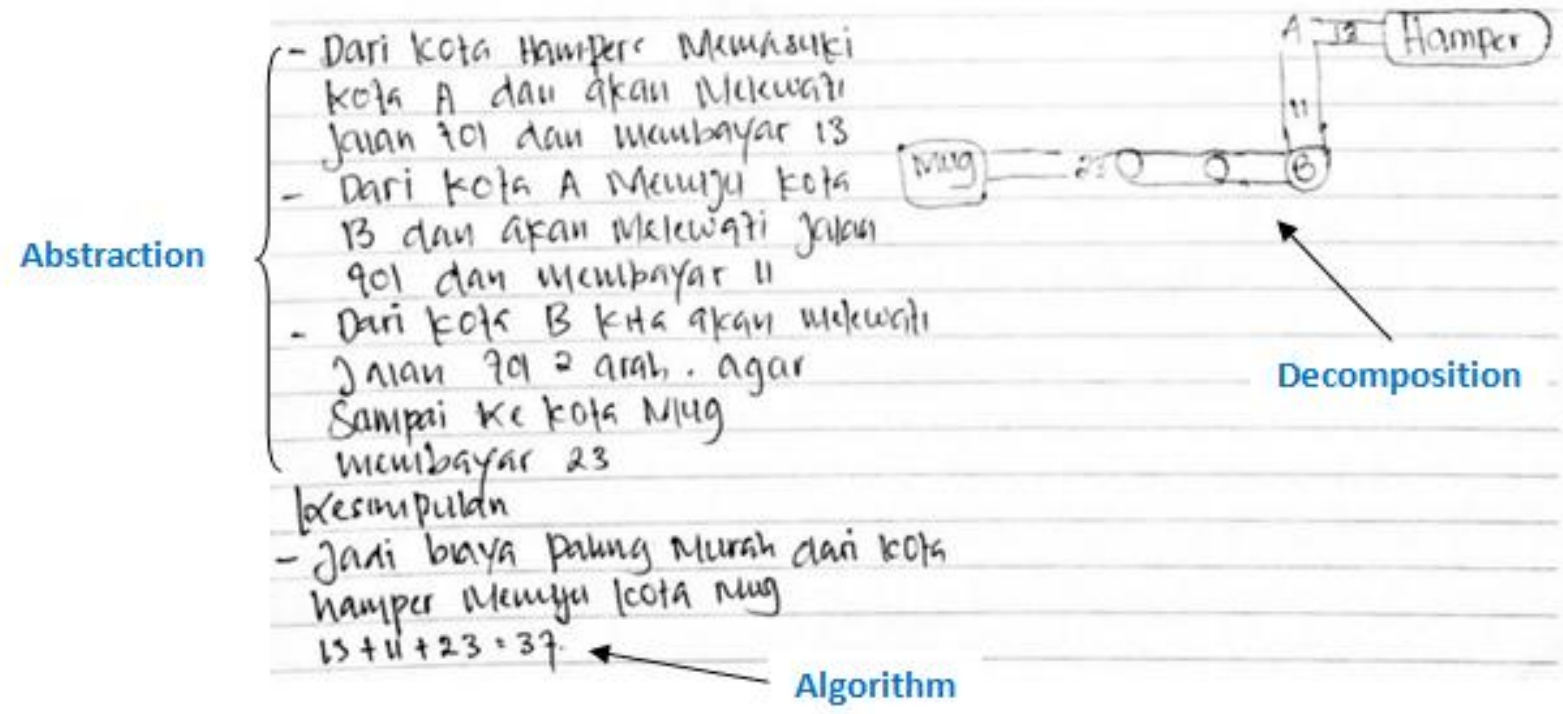

Gambar 3: Jawaban soal 2 salah satu responden

Gambar 2 dan 3 menunjukkan bahwa Computational Thinking responden dimulai dengan komponen decomposition, abstraction, dan algorithm. Sedangkan komponen generalization tidak terlihat dalam proses penyelesaian masalah. Urutan ini tidak sesuai dengan urutan komponen Computational Thinking yang dikemukakan Angeli et al. (2016). Voskoglou \& Buckley (2012) menyatakan bahwa urutan langkah penyelesaian masalah berdasarkan Computational Thinking tidak harus berurutan. Saat responden melakukan decomposition dan abstraction, pada tahap ini responden memahami masalah dengan membaca soal berulang kali sehingga semua informasi dalam soal dipahami. Hal ini terlihat dari bagaimana responden menuliskan kembali apa yang diketahui dan ditanyakan. Proses ini membelajarkan responden proses berpikir menyelesaikan masalah. Kosko \& Wilkins (2010) dalam Yuntawati (2017) 
mengemukakan bahwa siswa yang menulis untuk menjelaskan atau menggambarkan strategi-strategi memperoleh solusi akan mengalami peningkatan dalam keterampilan menyelesaikan masalah. Berdasarkan wawancara dengan responden, kesalahan yang dilakukan dikarenakan kurangnya responden dalam memahami soal yang diberikan. Soal yang diberikan hanya dibaca sekali atau dua kali sehingga informasi yang tekandung dalam soal belum benar-benar dipahami. Bahkan beberapa dari responden hanya melihat jalur termudah atau yang paling sederhana saja dan mengabaikan jalur yang berliku dalam menyelesaikan soal kedua.

Responden menunjukkan proses algorithm secara terurut langkah demi langkah untuk mendapatkan solusi yang benar. Pada proses ini ketelitian dan kecakapan dalam melakukan perhitungan juga sangat menentukan ketepatan solusi masalah. Dayanti (2014) menyatakan bahwa ketelitian adalah hal yang sangat penting karena ketelitian dalam suatu bidang dapat memprediksi prestasi kerja seseorang. Sedangkan Kamsiyatun (2016) mengemukakan bahwa matematika dan berhitung tidak dapat dipisahkan karena kemampuan berhitung merupakan salah satu bagian dari kemampuan matematika. Oleh karena itu ketelitian dalam berhitung sangat penting dalam menyelesaikan masalah.

Secara umum dapat dikatakan bahwa Computational Thinking tidak hanya digunakan untuk merujuk pada ide dan konsep dalam penerapan berbagai bidang Computer Science (CS) atau Teknik Informatika.tapi juga pada pendidikan matematika. Setiap masalah matematika yang dihadapi pasti ada pemecahannya dan Computational Thinking akan membantu menyelesaikan masalah dengan logika yang baik

\section{SIMPULAN DAN SARAN}

Responden mampu menyelesaikan masalah dengan komponen Computational Thinking. dimulai dengan decomposition, abstraction, dan algorithm. Sedangkan komponen generalization tidak terlihat dalam proses penyelesaian masalah, meskipun ada beberapa responden yang menjawab salah. Hal ini dikarenakan responden kurang memahami soal. Soal hanya dibaca sekali atau dua kali sehingga informasi dalam soal belum benar-benar dipahami. Bahkan responden hanya melihat jalur yang paling sederhana saja dan mengabaikan jalur yang berliku dalam menyelesaikan soal kedua.

Computational Thinking membantu peserta didik dalam menyelesaikan masalah matematika. Pengembangan Computational Thinking jika dilaksanakan dalam suatu cooperative learning membuat pembelajaran matematika menjadi lebih efektif. Sebuah masalah diberikan, didiskusikan bersama-sama dalam kelompok kecil atau besar terkait sudut pandang melihat masalah, kemungkinan - kemungkinan solusi yang dapat digunakan dan bagaimana proses pembelajaran yang didapat dalam masalah tersebut.

\section{DAFTAR PUSTAKA}

Adler, R. F., \& Kim, H. (2017). Enhancing Future K-8 Teachers' Computational Thinking Skills Through Modeling and Simulations. Journal Education and Information Technologies, 23(4), 1501-1514 
Angeli, C. et. al. (2016). A K-6 Computational Thinking Curriculum Framework: Implication for Teacher Knowledge. Journal of Educational Technology \& Society, 19(3), 47-57

Asiyah, A., Topano, A., Walid, A. (2021). Pengaruh Problem Based Learning (PBL) Terhadap Kemampuan Pemecahan Masalah dan Hasil Belajar Kognitif Siswa SMA Negeri 10 Kota Bengkulu. Edukatif: Jurnal Ilmu Pendidikan, 3(3), 717-727

Barr, V., \& Stephenson, C. (2011). Bringing Computational Thinking to K-12: What is Involved and What is The Role of Computer Science Education Community? ACM Inroads, 2(1)

Csizmadia, A. et. al. (2015). Computational Thinking: A Guide for Teacher. Computing At School: The Educational Division of Hachette UK

Dayanti, R. W. (2014). Pengaruh Komunikasi Interpersonal, Ketelitian (Conscientiousness) dan kepuasan Kerja Terhadap Kinerja Kepala Sekolah PAUD di Medan Deli. Jurnal Pendidikan dan Kepengawasan, 2(2), 55-70

Kamsiyatun, K. (2016). Pemanfaatan Media Gambar Untuk Meningkatkan Hasil Belajar Matematika Siswa Kelas IA SDN Sidomekar 08 Kecamatan Semboro Kabupaten Jember Tahun Pelajaran 2014/2015. Pancaran, 5(2), 91-102

Maharani, S., Kholid, M. N., Pradana, L. N., \& Nusantara, T. (2019). Problem Solving in The Context of Computational Thinking. Journal of Mathematics Education, $8(2), 109-116$

Maharani, S., Nusantara, T., As'ari, A. R., \& Qohar, A. (2019). How The Students Computational Thinking Ability On Algebraic? International Journal of Scientific \& Technology Research, 8(9), 419-423

Masfingatin, T., Maharani, S. (2019). Computation Thinking: Students On Proving Geometry Theorem. International Journal of Scienctific \& Technology Research, 8(9), 2216-2223

Meha, A. M., \& Bullu, N. I. (2021). Hubungan Kesiapan Mengajar da Proses Praktik Pengalaman Lapangan dengan Keterampilan Dasar Mengajar Mahasiswa Pendidikan Biologi. Edukatif: Jurnal Ilmu Pendidikan, 3(2), 412-420

Selby, C. \& Wollard, J. (2013). Computational Thinking: The Developing Definition. Conference: Special Interest Group on Computer Science Education (SIGCSE). Diakses dari https://www.researchgate.net/publication/299450690_Computational_thinking the _developing_definition

Selby, C. 2014. How Can The Teaching Programming be Used to Enhanced Computational Thinking Skills? (Unpublished doctoral dissertation). University of Southampton, Southampton,UK. Diakses dari https://eprints.soton.ac.uk/366256/

Voskoglou, Michael Gr. \& Buckley, Sheryl. 2012. Problem Solving and Computers in 
Learning Environment. Egyptian Computer Science Journal, 36(4), 28-46

Wing, J. M. (2011, March). Computational Thinking. Diakses dari https://csta.acm.org/Curriculum/sub/CurrFiles/WingCTPrezpdf

Yuntawati, Y. \& Aziz, L. A. 2017. Problem posing Setting Kooperatif untuk Meningkatkan Kemampuan Menyelesaikan Masalah Matematika Siswa. Jurnal Kependidikan, 3(1), 180-191 